\title{
The Schreber Connection: Interpretation in psychoanalysis and
} literature

\author{
L. Herman, Bart Vervaeck
}

\section{Citer ce document / Cite this document :}

Herman L., Vervaeck Bart. The Schreber Connection: Interpretation in psychoanalysis and literature. In: Revue belge de philologie et d'histoire, tome 61, fasc. 3, 1983. Langues et littératures modernes - Moderne taal- en letterkunde. pp. 591-608; doi : https://doi.org/10.3406/rbph.1983.3433

https://www.persee.fr/doc/rbph_0035-0818_1983_num_61_3_3433

Fichier pdf généré le 14/04/2018 


\title{
BIBLIOGRAPHIE - BIBLIOGRAFIE
}

\author{
The Schreber Connection : \\ Interpretation in psychoanalysis \\ and literature $\left({ }^{*}\right)$
}

\section{Luc Herman \& Bart Vervaeck}

In an effort to compensate for the loss of authority the psychoanalytic theory has suffered in the domain of literary criticism. several critics have not only detected parallels between the two disciplines, but also posited that both should inform and thereby 'enrich' each other ${ }^{(1)}$. In Barry Chabot's view as well. psychoanalysis and literary criticism should be reciprocally connected. firstly because both disciplines aim at "the understanding of another through an understanding of his or her language" (p. 4). Secondly, both psychoanalysis and literary criticism must presuppose the coherence and cohesion of life ; without "such an assumption, there would be no reason to interpret something one way rather than another" (p. 5). The third parallel between psychoanalysis and literary criticism immediately follows from the first two : the objects of both psychoanalysis and literary criticism should be conceived "through, and as, coherent written documents“ (p. 10).

On a more general level, Chabot characterizes the relation between psychoanalysis and literary criticism in terms of homologies : psychoanalysis stands to literary criticism as outside stands to inside (p. 50) ; psychoanalytic theory stands to psychoanalytic practice (interpretation) as it stands to literary criticism (pp. 151-152). Psychoanalysis contributes "to literary studies the

(") Снавот (C. Barry). Freud on Schreber: Psychoanalytic Theory and the Critical Act. Amherst. University of Massachusetts Press, $1982.174 \mathrm{pp}$.: éen deel $23.5 \times 15.5 \mathrm{~cm}$. Prijs : $\$ 17.50$.

(1) See, e.8., S. Felman (1977: 5-10). 
substantial benefits of its psychological theory". whereas literary studies contribute to psychoanalysis "the benefits of their recognition of the linguistic nature of their evidence" (p. 152). Taken together, all this suggests that psychoanalysis stands to literary criticism as theory stands to practice.

To drive home these points. Chabot studies Schreber's Memoirs of my nervous illness $\left(^{2}\right)$ as a literary text, thereby turning Freud's essay on this text into "an exercise in literary criticism" (p. 2), and, better still, into "a model for all literary interpretation" (p. 75). However, Chabot never offers a theory about literariness and about texts. Without such a theory, the distinctions between the various texts and more specifically between 'insanity' and 'art', tend to be obscured. Chabot states without any argumentation that Schreber's book is "a work that is at once clinical document and literary exercise" (p. 1). It is never made clear why this is so. that is. why a text may be an articulation of 'insanity' and/or of literary creativity. If texts are reduced to "coherent written documents" (p. 10), they are stripped of their uniqueness. Putting aside the insufficiency and vagueness of a concept such as "coherence", one might argue that legal, sociological and political documents are coherently written, but it is very hard to see how Chabot's approach could be applied to these sorts of texts. In other words : due to the lack of a theory about (literary) texts. Chabot negates the distinctiveness of each and every text and fails to delineate the scope of his approach.

The only limitation that Chabot imposes upon his theory is of a linguistic nature. In his view, psychoanalysis and literary criticism deal with language and more specifically with written documents. While this may seem undeniable for literary criticism. it is a false reduction of the domain studied by psychoanalysis. For one. psychoanalysis does not mainly study written texts. More importantly, as long as psychoanalysis restricts itself to language. it will remain an external and a posteriori approach. One of the most promising trends in recent psychoanalysis precisely aims at revealing the overriding importance of the non-verbal, the symbolic. Anzieu (1981), Rosolato (1978), Sami-Ali (1977), Pankow (1969), Sibony (1974). Jeddi (1982) and many others have shown the crucial importance of the body in the construction of a meaningful universe in which one can live. The relation between bodiliness and language, analogue and digital, prereflexive and reflexive, primary and secondary system, is essential to any understanding of the subject-in-his-world. As long as one limits oneself to language, one cannot possibly hope to arrive at an internal-dynamic theory of the way in which a person constructs his (being-in-his) world. Language is situated at the level of

(2) This book was first published in 1903. In the German language, it is available in the 1973 edition. The English translation (from which all our references are drawn) dates from 1955. 
representations : to start from this level in order to arrive at the so-called deep level is a very dubious affair since representations are always transformations (and never faithful reflections) of this underlying level (cf. Bourdieu 1980a).

This is especially clear in the Schreber case : times without number Schreber mentions his body as the central locus and agens of his (psychotic) worldconstruction. Only, and precisely, after he had "had a quite unusual number of pollutions (perhaps half a dozen)" (Schreber 1955: 68), did "the first signs of communication with supernatural powers" (ibid.) appear. All attacks by God. Flechsig and any other aggressor, are destroying his bodiliness (see e.g. Schreber's description of what he calls "the miracles", which are essentially changes in his bodily experiences). Most significantly, it is precisely through the transformation of his body into a female body that he articulates his delusional world.

The importance of the body in Schreber's psychosis is completely neglected by Chabot as by so many others ${ }^{(3)}$. Restricting the object of psychoanalysis and literary criticism to "understanding strings of words" (p. 50), Chabot impoverishes both disciplines. Surely, psychoanalysis also deals with the (non-verbal) movements of patients, the way they walk, dress. talk, etc. Along the same lines, we have argued elsewhere (Vervaeck 1982) that literary criticism is incomplete and misleading if it restricts itself to language.

Due to this restrictive starting point, Chabot denies himself the possibility to study psychosis as a production instead of a mere product (viz., a text). This entails that he is obliged to start from a text written after "the event" and to try and infer from this the underlying coherence. Chabot may state that psychoanalysis is not deductive (pp. 72-73), but by narrowing it to the linguistic aspect, he inevitably turns psychoanalysis into a hypothetical and abstract discipline that starts from concrete documents to arrive at more general, abstract and hypothetical structures.

This is obvious in Freud's essay on Schreber. Freud (1958) reduces the vast multi-dimensionality of Schreber's world to one basic proposition, viz., "I (a man) love him (a man)". All sorts of operations are then performed on this proposition. so that the paranoiac finally arrives at the proposition : "I hate him because he persecutes me". Leaving aside the reductionism of this approach, it should be clear that this method implies a hypothetical reversal of the internal dynamic. Indeed, according to Freud, Schreber starts from "I love him" and then goes to "I hate him", whereas Freud starts from the latter and goes to the former (cf. Chabot

(3) See, e.g., the overriding importance attached to language by O. Manonni (1969). A. Green (1977) and J.-F. Rabain (1980). One exception is J.-L. Schefer (1977). For a summary of the most important Schreber-interpretations, see H. Israels (1980) and P.-C. Racamier \& J. Chasseguet-Smirgel (1966). 
1982 : 43). This approach, then, starts from the product, postulates a deep structure ("I love him") and all sorts of transformations (negation, projection, and so on), and claims that this postulation shows the internal dynamic, that is (in this case), claims that this is what Schreber is actually doing.

This reversal of the internal dynamic ties up with Freud's reversal of causality. As it is analyzed by Freud, Schreber's delusionary substitution of his psychiatrist (Flechsig) by God, provides a clear example of this reversal. According to Freud (and Chabot : p. 45), the substitution is effectuated because it turns Schreber from Flechsig's whore into the wife of God. This enhances his status, turns lust into a holy duty and makes his femininity (homosexuality) acceptable for the ego. However, this is a false causality. What one can see is : if $A$, then $B$, viz., if Schreber replaces Flechsig by God, then his homosexuality becomes acceptable. Quite wrongly, Freud concludes from this : if $B$, then $A$ : Schreber wants to make his homosexuality acceptable, hence he has to replace Flechsig by God. Not only does this imply a logical mistake, it also fails to explain the form of the substitution. Why, of all possibilities, should Schreber select God to replace Flechsig?

Due to these reversals of causality and of the internal dynamic. Freud fails to arrive at a description of the processual sequence by which Schreber's psychotic world is constructed. All the various steps that Freud detects in Schreber's delusions (1958: 35ff. : cf. Chabot 1982:48) are never clearly related and their order of succession may always be reversed. Chabot does not mention these mistakes in Freud's essay. As we shall see, he partly makes the same faults when he uses Freud's essay as the foundation of his own theory of interpretation.

\section{Chabot's approach}

1. The shortcomings of Chabot's approach are inherent in his restrictive point of departure (language). They may be explicitated starting from his radical dichotomy between theory and interpretation. Chabot argues that an interpretation does not need a theory and that the validity of one of the two does not imply the validity of the other (pp. 52-53,144ff.). They are part and parcel of quite different realms of discourse : theory $v$. practice, general $v$. individual, genetic $v$. thematic, abstract v. concrete (p. 144).

Chabot's point of view enables him to bring out the inadequacy of the common and current psychoanalytic interpretations of literature (p. 151 ff.). This traditional sort of interpretation uses theory to consolidate and legitimate the interpretation by giving it a scientific air : it reduces the specificity of literary texts by applying without further ado psychoanalytic theory to these texts ; it implicitly over- 
estimates psychoanalysis as a scientific theory while underestimating literary criticism as a subjective enterprise desperately in need of a firm theoretical backbone.

But Chabot's division is full of ambiguities and contradictions. Firstly, he suggests that psychoanalysis stands to literary criticism as theory stands to interpretation (pp. 151-152). However, he states that the relation between psychoanalysis and literary criticism is reciprocal (p. 6) whereas the relation between theory and interpretation is, still in his view, dichotomous (p. 144). Secondly, he claims that it is wrong to use theory in interpretation (p. 53) : "The interpretive realm (is) mystified as to its own nature (when) it comes garbed in the language of theoretical discourse, a language that is both unnecessary and inappropriate" (p. 145). At the same time. however, he contends that there can be no interpretation without theory: "Psychological theory, then, is a necessary preliminary to, or a condition for, the interpretive process" (p. 50 ; cf. pp. 74-75). Along the same lines, he insists that theory can offer no validation for interpretations, "for there is no reciprocal relation between the adequacy of specific interpretations and the theories that suggest them" (pp. 53-54). But again. he himself uses psychoanalytic theory to evaluate literary criticism. For instance. he discards the traditional psychoanalytic interpretations of literature because they "misconstrue the complex causality posited by psychoanalysis" (p. 59) and because "they ignore the potential self-sufficiency of the present (here, of the text) that psychoanalysis implies" (p. 61). And again: he justifies the enabling assumption of interpretive discourse (viz., the cohesive life) via psychoanalytic theory: "I shall demonstrate its justifications within psychoanalytic theory" (p. 64). He even states that "the extent to which interpretations comply with them (i.e., with general theoretical propositions - LH \& BV) is an important criterion of their accuracy" (p. 70 : cf. pp. 73-74).

In order to save his fundamental dichotomy while retaining the importance of theory for interpretation. Chabot posits that theory has a three-fold dircctive role in interpretation : (1) "It defines the nature of the object of interpretive discourse". (2) it serves "as a series of pointers to potentially relevant issues and information in (the interpretation)", and (3) "to the extent that a comprehensive and coherent interpretation complies with theory, the interpretation is weakly confirmed" (pp. 148-149 - Chabot's italics). It is unfortunately not clear in Chabot's book what this "weak" confirmation consists of. Moreover, if theory fulfills these roles in interpretation, it is hard to see why it should be banned from interpretive discourse. At any rate. these roles do not legitimate Chabot's dichotomy.

One of the remarkable aspects of Chabot's division is precisely that it is never legitimized by firm argumentation but by references to authorities esp. to Schafer (e.g., pp. 52-53). Ironically, Chabot himself states later on that "the use of a 
technical vocabulary represents little more than a crutch or appeal for authority ; it tends to proliferate at precisely those junctures of the exposition most in need of authority, that is, where it is weakest, as if its mere presence could patch over the difficulty at hand" (p. 145).

All this does not imply that one should do away with Chabot's division between theory and practice (interpretation). They do inhabit different realms, but this does not entail that they are discontinuous. The relation is far more complex and cannot be captured in dualistic terms, as Bourdieu (1980a) has elucidated.

However. Chabot refines his dichotomy and turns it into a triadic relation. He then distinguishes between (1) "the theoretical realm" preoccupied with "genetic and historical concerns", (2) "the therapeutic or interpretive situation", i.e., "the realm of technique", and (3) the "realm of psychoanalytic interpretive discourse" that takes "the form of a coherent narrative" (pp. 61-62). The emergence of this triad may be seen as a strategic move on the part of Chabot to salvage the parallel he has drawn between psychoanalytic and literary interpretation. Indeed, a critic cannot interfere with his text, at least not in the same way as an analyst can interfere with his analysand (e.g., an analyst can influence and change the utterances of the analysand. he can trigger off certain reactions, etc.). As a result. the two interpretive practices are not the same, so that Chabot's parallel is not a completely accurate one. By positing a realm of psychoanalytic interpretation proper. Chabot creates a psychoanalytic 'text' - comparable to the literary one that is the neat precipitate of, among other things, the techniques used during the analysis. This text can be interpreted, and as such the interpretations in analysis and literary criticism are analogous.

Chabot further argues that these realms should be neatly kept apart, since they "are quite distinct" (p. 62). This, however, reproduces the breach between theory and practice, the latter now being internally divided into technique and interpretation. Chabot overstresses the separateness and obscures the relatedness (cf. the "weak" confirmation and the directive roles). This runs against his own attempt to speak in terms of relations rather than in terms of entities (cf. infra).

2. If interpretation is not to be structured by theory. it is necessary to describe the procedure and logic specific to interpretation. Chabot sets out to do so on the basis of Freud's essay on Schreber. Strangely enough, he repeatedly states that Freud's essay is not an interpretation at all, since it uses the Schreber case as a mere illustration of a theory of paranoia (e.g.. p. 52, 108). One of the fundamental methodological mistakes that endangers the value of Chabot's whole work, is precisely this contradiction : how can Chabot use Freud's essay as a "model for all literary interpretation" (p. 75) when he himself demonstrates that the essay is not even an interpretation but merely "'Notes' toward an interpretation he (i.e., Freud - LH \& BV) never wrote" (p. 52). In other words : Chabot builds his theory of 
interpretation on (the analysis of the interpretive procedures and logic in) a text that he does not regard as an interpretation.

Chabot goes on to argue that interpretation should never be genetic or historical because such "excavation in psychoanalysis inevitably and necessarily opens up an infinite regress" (p. 55). This means that one can never arrive at some primal original source, a 'simple fact' that would be at the beginning of, say, a patient's history. Indeed, this original 'fact' is never simple or real : it is itself constructed, "permeated with, even constituted by, fantasy, memory, the unreal" (p. 56). Chabot rightfully argues that the psychoanalytic searchings for some original event as the basis of everything that follows, are founded on "the illusion of the Real" (p. 152 ; cf. pp. 54-62), that is, on the mistaken idea that real events may exist at the beginning without being permeated by irreality and restructured by what follows.

This implies that interpretation in Chabot's view should restrict itself to the present. Indeed, the past always structures the present and is restructured by it (p. 57) : hence, in the present one can detect the past and vice versa. This means that "the present (is) in principle sufficient", that "the past is hopelessly elusive" (cf. the illusion of the Real), and that the past is "dependent upon the present it figures" (pp. 58-59). Historical excursions, such as biographical essays, are thus neither necessary nor sufficient conditions for an interpretation (p. 60). At the same time, however, Chabot recognizes the importance of diachronic studies, but limits these to the realms of theory and technique (pp. 61-62).

Chabot's view on the illusion of the Real and on the interdependence of past and present has many positive aspects. For instance, it reveals the fundamental flaws in the traditional psychoanalytic interpretations of literary works (p. 59), it demonstrates the diffuseness of historical interpretations, etc. But. while Chabot argues that genetical-historical procedures should be banned from the interpretive realm, he himself falls prey to such procedures. As we shall see, Chabot reduces Schreber's psychotic world to one fundamental conflict (viz., the "fragile sense of autonomy", p. 137) which "greatly antedates his breakdown" (p. 136) and which turns the whole of Schreber's life into an attempt to remediate this conflict ( $p$. 143). In other words. Chabot himself is looking for sources, beginnings, original events that lie at the heart of the whole universe-construction and that somehow "antedate" and "anticipate" (p. 130) this construction. Along the same lines (and correcting Freud somewhat). he argues that Schreber's "paranoid ideas derive from" the process that turns "I love him" into "I hate him" (p. 38). Again. this implies an original source. a process in time and a result - certainly a genetic procedure (cf. p. 65). What sets Chabot apart from the more traditional genetic approaches. is that he tries to insert all events into a network, a pattern, so that a multi-dimensional causality takes the place of mono-causality. Rather than doing 
away with all genetic explanations and interpretations (as he pretends to be doing). Chabot is refining them. It is thus very misleading on his part to represent all genetic explanations without distinction as causal and reductionist (p. 148). and to present his own approach as new and non-genetic.

More importantly. Chabot's approach has a distinctly subjectivist and linear flavour. Reality is undeniable constructed. the Real does not exist. But this construction does not come out of the blue : it is structured by what it structures (viz. 'the Real'), as Bourdieu (1980a) has convincingly argued. Chabot largely neglects the importance of this reciprocal and orientated relation (that is called double articulation): he posits a fundamental structure (viz.. autonomy) that antedates the structuring process. Admittedly. Chabot occasionally suggests that elements within the network are structuring and structured at the same time. For instance : the present structures the past and is structured by it (p. 66), the subject structures the relations and is structured by them (p. 106). However, Chabot nowhere offers any theory to account for this double articulation. Moreover. the fundamental conflict is seen as the basis of all this : it seems to be structuring rather than structured (p. 87), because it is the beginning that constitutes the network and that somehow precedes it.

The nature of the construction (in this case, of a psychotic world) can only be brought in the open when one scrutinizes the "forces" or structures that at the same time construct and are constructed by this construction. Chabot overstresses the construction as a product and neglects the productivity. As a result. the specificity of Schreber's world construction seems to be a decision, a choice. maybe an irrational or incomprehensible caprice :

I suggest, then. that (Schreber's) concern with autonomy greatly antedates his breakdown (...). After 1893, Schreber for some unknow'n reason displaces these same interests. so that the Order of the World replaces the German Law. (p. $136-$ italics added).

This passage clearly shows Chabot's approach to be genetic. It also shows his incapability to account for the form and transformation within this genesis : why, of all things, should the Order of the World as Schreber conceives it, replace the German Law? This incapability follows from Chabot's negligence of the double articulation : the form of Schreber's construction is the outcome of the structuring structures being restructured by the process they structure.

All this goes to show that Chabot's genetic approach falls short on three accounts : (1) it presupposes something pre-existing (viz., autonomy), something that antedates the process of universe-construction. whereas we have argued that nothing exists unless it is articulated. constructed in this process : (2) it cannot account for the transformations effected on that "something" within the process ; 
(3) this is due to the fact that it studies the construction as a product while neglecting its production.

The third aspect of this failure clearly comes out in Chabot's view on the autonomy of the present product (e.g.. a text). Chabot posits "the potential selfsufficiency of the present" (p. 61) and adds that "the text is in principle selfsufficient" (p. 59). We have criticized this viewpoint extensively elsewhere (Vervaeck 1982). Suffice it to say that such a view negates the structuring of the present product by a process of double articulation that is partly autonomous and partly dependent upon other factors (economy, politics, etc.). Chabot thus obscures not only the relation between product and production, but also between autonomy and dependency. More specifically: Chabot never elucidates the transformation between present and past because he restricts himself to the present as a product in which the past only exists in its already transformed dimensions. He can never grasp what the transformation is all about, because he only studies the outcome of it (i.e., the product). "The present - be it a text or clinical situation - alone suffices, if we could but see it properly“ (p. 147). It seems to us that it is impossible to see the present properly unless one sees it in its dynamic, productive relation with the past, and not as a sort of container of the past.

Chabot's viewpoint on autonomy thus installs all sorts of dualisms (autonomy $\mathbf{v}$. dependency ; product $\mathbf{v}$. production) which seriously undermine his project of developing a relational theory that would transcend all dualisms (cf. infra). As we have demonstrated above, this dualistic approach is a corollary of the narrowly linguistic starting-point that gives access to the product rather than to the production.

3. According to Chabot, interpretation should not be genetic or inspired by theory. Rather, it should be semantic and holistic. This means that interpretation should bring out meaning, and since meaning only exists in relation to". interpretation must bring out a pattern of relations, an all-comprising network. This is possible only when one presupposes that there exists a fundamental interrelatedness and coherence between the 'facts' that are to be interpreted. Chabot calls this the enabling assumption of cohesive life: psychoanalysis and literary criticism must presuppose "the radical continuity of that life" (p. 64) since otherwise there can be no network of meaningful relations and thus no interpretation.

This continuity and coherence is guaranteed by (and can be captured in terms of associative chains. Chabot explains this crucial concept on the basis of the theories of Erikson, Lichtenstein and Freud. Erikson has shown the dialectical interaction between identity and ideology : both are defined in the reciprocity that exists between them (p. 81). Life is then seen as a continuous process of syntheses between identity and ideology (cf. subject and society, self and other) which are 
effected in the interaction between the two (pp. 82-83). Chabot shows that this theory needs refinement to bring out the full weight of the relational dimension of the subject and his life.

Following Lichtenstein. Chabot sees the identity-theme as the relational identity that is formed and "engrafted" in the relation with the mother $\left({ }^{4}\right)$. The subject articulates itself in this relation, it is a relation. All other and later relations are transformations of this fundamental relation which thus makes life into a coherent network of relations. In other words : the identity-theme is the basis of the subject as a relation and of the cohesive life.

Freud's concept of transference provides a similar base for the enabling assumption : transference is the process that brings the past into the present by inserting the analyst into the chain of relations structured by the past. Transference generates a "new edition or reprinting" of an old theme (p. 101). On a more general level (i.e., not limited to the therapeutic situation), transference is the process whereby everything becomes a reprint of former themes, thus generating chains and cohesion. Again, this fundamental dimension (transference) is relational : it is situated in the relation between "subject" and "environment". One can detect these chains with the help of the associative method (p. 94ff.).

All this means that there exists a fundamental relation (identity-theme, transference) which articulates the subject in relation to his environment and which thereby generates the cohesion of his life through the production of chains that link all events, relations, persons, etc. to the fundamental identity-theme. On a still "deeper" level, this fundamental relation can be shown to be a "structuring conflict" (p. 97). This conflict forms the link between all elements of life and thus generates the relations, the associative chains and the cohesive life. Dreams, works of art. etc., are homologous transformations of this basic conflict : all chains are homologous since they are structured by the same conflict that is transferred onto and via them. Interpretation thus becomes the attempt to detect this basic element that unites all phenomena : the interpreter "confronts the totality of his data and attempts to bring it, at once, with a simple, economic hypothesis, to understanding" (p. 67).

Chabot's expose of the articulation of coherence on the basis of conflicts is the core of his book and by far the most important contribution he makes to both psychoanalysis and literary criticism. Our summary merely provides the

(4) This might be compared to Rosolato's concept "relation d'inconnu" (1978) and to the engrafting of "pictogrammes" (Aulagnier 1975). However. these authors do not fall into the trap of reification that has certainly caught Lichtenstein and Chabot who reduce the surplus and the unknown in every relation ( $\mathrm{p} .97)$ to one relation that is substantialized in the relation with the mother. 
headlines of his detailed account, but it allows us to show that, for all the merits his approach has, it also raises fundamental questions.

Firstly, if interpretation presupposes the continuity between past and present. the interpreter would be well advised not to discard historical excavations (cf. supra). Secondly, the presupposition is too rigid : it reduces all sorts of breaches to 'mis-articulations' of the fundamental continuity (pp. 105-106). Foucault, writing a history "des ruptures" (1969: 15) and "de discontinuite" (id.: 16), has convincingly demonstrated how misleading and erroneous the ideas about coherence and continuity may be. In his terms, Chabot's essay would be an attempt to write what can never be written, viz., "une histoire globale" (id. : 17) i.e., a history in which all things are reduced to a few fundamental hypotheses instead of writing "une histoire generale" (ibid.) that focuses on changes, breaches, discontinuities, etc. (id. : 216-231).

Thirdly, the problem of the transformations remains. According to Chabot, all phenomena are "transformations of a primal mode of relatedness" (p. 105), and these transformations are thought to be effected within the associative chains. However, it remains unclear what sorts of transformations are involved since it remains unclear what sorts of associations are involved. Chabot merely states that associations and transference are crucial in these chains, but their precise role is not explained. In our view, it is better to characterize these chains and transformations generally in terms of metaphorical and/or metonymical relations (cf. Rosolato 1978 : 52-80). These two processes cover the whole range of psychoanalytic processes such as projection and deplacement (cf. Zenoni 1976), while they also bring out the relations and differences between these processes.

Closely related with Chabot's incapability to discuss the particular form of the associations is his incapability to describe the nature of the transformative links in the chains. He states that the chains are not "free" (p. 66), but the nature of the determinative process (articulating itself in this chain) remains a mystery.

Fourthly, due to the reduction of all phenomena to one basic conflict and due to the breach between theoretical discourse and interpretive discourse, Chabot reduces his interpretations to paraphrases of "le sens commun" in which all multidimensionality is seen as an elaboration of one basic dimension. We shall elucidate this when we discuss Chabot's interpretation of Schreber (cf. 4. infra).

Fifthly. Chabot's theory about the interpretive process may be very revealing for psychoanalysis, but it seems less accurate for literary criticism. In literary criticism. there is no transference as in psychoanalysis. As has been suggested, a reader cannot change the 'course' of a text, and a text cannot transfer its problems onto its reader. On the other hand. an analyst can change his analysand, and the latter can (and does) transfer his problems on his analyst. The fundamental difficulty with Chabot's approach is that he seems to think that interpretive 
procedures that hold for the therapeutic situation. will also hold for the literary situation. Chabot never even mentions the particularities of the process of reading and interpreting a literary text $\left(^{(5)}\right.$.

However. Chabot does mention the third realm, that is, the domain of interpretive discourse. In his view. psychoanalytic interpretations (e.g., of a novel) should take the form of a narrative (cf. Kuiper 1976). This follows directly from his relational assumption :

The very nature of the cohesive life (...) dictates that its proper understanding take a narrative form. Because for both (i.e., for Freud and Lichtenstein - LH $\&$ BV) the subject has no existence apart from or prior to the series of rclationships in which it is both constituted and constitutive, defined and defining, we can only grasp it through an understanding of these temporal relationships. (p. 106).

In other words, psychoanalytic interpretation is a story that paints the cohesive life and that is grounded in the fundamental relational characteristics of the subject. The form of the narrative is not serial : it is structured by the movement within the associative chains. These chains have no "definitive first link" (p. 66), they rather imply a continual shifting from present to past and vice versa. That is, in these chains "attributes slide forward (which we call 'transference') and slip backward (which we call 'deferred action')" (p. 66). It is precisely this perpetual movement that ensures the links, the relations, the coherence: "Each link becomes a veritable palimpsest, rewritten time and again" (p. 107). This implies that the psychoanalytic narrative is fictive, because it deals with events that are always being rewritten and restructured by fantasy, desires, etc.. "so that no single inscription can be clearly disengaged" (p. 107). This does not turn psychoanalysis into fiction because all the reprints can be traced to one fundamental "first edition', the identity-theme.

This. however, does not solve the problem of psychoanalytic interpretations of literature. Firstly. one may question the validity of Chabot's argument that the relational pattern can only be understood in and through a narrative. A scheme, a mathematical enumeration. statistics. etc. - all these may equally capture the relational qualities of what they represent. Secondly. Chabot gives no details about the actual form that the narrative ought to take. The movements within the

(5) Most readers and literary critics assume a fundamental textual coherence in their search for the meaning of a literary work. For a detailed description of this assumption and its consequences (e.g.. the logical link with authorial intention, the status of textual evidence in interpretation, the evaluation of interpretations with reference to the amount of facts that are united under the "coherent" reading), see Juhl (1980). 
chain may structure that form. but they do not determine it. These two arguments indicate that Chabot's attempt to posit a determinative relation (between relatedness and narrative : between associative chains and form of the narrative) is not particularly successful.

Thirdly, because Chabot presupposes that both literary criticism and psychoanalysis deal with texts, and because he neglects the difference between the various sorts of texts, he is able to step. seemingly without problems, from the psychoanalytic interpretation in the analytic situation to the psychoanalytic interpretation of literary texts. This, however, denies the specificity of both sorts of interpretations. Chabot is right in saying that psychoanalysis should not interpret literary texts, its characters and its authors as if these were patients (p. 59). But he himself never arrives at explicitating the difference between the literary and psychoanalytic situation. This can be discerned easily in his statement that "the theoretical discourse of psychoanalysis can serve interpretive discourse within literary studies precisely as it serves that within psychoanalysis" (p. 152 - italics added).

Still, Chabot notices a few differences between literary criticism and psychoanalysis. For one. psychoanalysis goes further than literary criticism. since it does not only want to understand the discourse, but also aims at changing it (pp. 7172). Secondly, literary criticism wants "to appropriate and so pass on a cultural heritage". whereas psychoanalysis aims at "the easement of personal suffering" (p. 73). Thirdly, psychoanalytic interpretation has a firm theory backing it up. whereas literary criticism lacks such a theory (pp. 73-74). As Chabot himself concedes. none of these differences touch the core of psychoanalysis and literary criticism. According to Chabot, the object, the task, the method, the evaluative criteria, and so on - all these are "indistinguishable" in both disciplines (p. 73). This is yet another aspect of the dissimulation of the specificity of psychoanalysis and literary criticism. The 'adaptation' that psychoanalysis must needs undergo when applied to the literary field, is never dealt with.

4. According to Chabot. Schreber's universe becomes meaningful when one interprets it as an attempt to find a solution for one fundamental conflict. viz., the endangered autonomy. All of Schreber's "sufferings reveal themselves as various transformations of this radical complaint : another's usurpation of his will" (p. 118). Chabot lodges "the issue of self-determination or autonomy in its many permutations at the thematic center of Schreber's Memoirs of My Nervous Illness" (p. 133). Not only Schreber is haunted by this "fragile sense of autonomy" (p. 137), the whole universe is. God, Flechsig, the rays, the little men, the souls, all creatures in Schreber's world are threatened in their autonomy (pp. 130-133).

This fundamental identity-theme (endangered autonomy) realizes itself in everything Schreber does. feels, or thinks. His "disavowed criticism" (p. 111) and 
suppressed aggression are attempts to convince the readers (of his Memoirs) of his rationality, his self-control and autonomy. However, this incessant pleading to win the readers respect and to convince them that he is a respectful man, is a form of bad faith : "He needs our respect because he doubts his own worth" (p. 140). In other words, Schreber is aggressive and lacks a firm sense of autonomy : his Memoirs are an attempt to convince the readers and thereby himself of the contrary.

Interestingly enough, this plea to be respected and this suppression of aggression makes Schreber into a non-exemplary case of paranoia. Freud's paradigm of paranoia has at its core hostility (cf. "I hate him") and indifference or suspicion with regard to the outer world (from which the paranoiac does not seek to elicit respectfulness) $\left.{ }^{6}\right)$. Schreber on the contrary hides his hostility and shows too much interest in the outer world (p. 138). Hence. Chabot refuses Schreber his long-standing status of the paradigmatic paranoiac $(7)$. His refusal is lined up with the dualism between theory and practice: in theory, paranoiacs openly show hostility and never plead to gain respect from the outer world. in practice Schreber does not meet these standards, therefore, his case is not typical (p. 138).

The fundamental identity-theme is also the structuring relation underlying Schreber's catatonic phase, his view on sleep as a crucial aspect of his illness, his unmanning, his soul voluptuousness, etc. (pp. 122-130). It is also the structuring force behind the miracles, the delusions, and so on.

Chabot's interpretation of Schreber is subtler than this summary may suggest. However, this sketch suffices to situate the main problems of his approach. Firstly, there is the obvious reductionism : a complex set of relations is reduced to one fundamental relation. Chabot rightly criticizes Freud (1958), Schatzman (1973) and Niederland (1974) because they reduce the uncertain, the surplus, the unknown of the Memoirs to "a more secure, less volatile ground upon which to base interpretation. In a word, such procedures seek the Real" (p. 147). This is very true indeed. but Chabot himself reduces the undefinable surplus of the Memoirs to something which is more secure and more real (in the sense of : more basic), viz., the endangered autonomy.

Secondly, this approach still remains genetic : the identity-theme is said to be pre-existing, it antedates the psychotic universe-construction (p. 129, 136 ; cf.

(6) This is a rather crude simplification that Chabot effects on Freud's paradigm. For a more detailed exposé of the Freudian paradigm of paranoia, see Meissner (1978, esp. chapter 1).

(7) Cf. Walters (1955) who has shown that the paradigm of paranoia need not feature suppressed homosexuality. The Schreber case, in which Freud proposed the inevitable link between homosexuality and paranoia, is not paradigmatical. 
supra). Along the same lines. Chabot describes Schreber's "catatonic phase as an anticipation of Schreber's eventual solution" (p. 130).

Thirdly. Chabot tends to fall into the trap of unilinear reasoning: it seems as if everything in Schreber's world is a reflection or a transformation of one source. On the basis of the study of the cohesive life, this source is posited, but it is never made clear how it is structured and articulated. This mystifies the double articulation of structuring (viz., identity-theme) and structured structures (viz.. the psychotic world as a transformation of this theme). It is misleading to speak of autonomy, or of any sort of identity-theme, because this autonomy only exists to the extent that it is articulated - which implies that it only exists in specific. restructured forms and never in the form of one global, general, underlying and pre-existing structure. This indicates that it is impossible to search for one basic relation that would explain the whole world of the subject. Since this search is precisely what Chabot understands by "interpretation" (p. 67 ; cf. supra), one must conclude that his project is an impossibility (cf. Foucault 1969).

This links up with the already mentioned incapability to explain the transformations that the abstract identity-theme undergoes so as to manifest itself in the concrete forms it receives in Schreber's psychotic world. According to Chabot, Schreber's "preoccupation with justice, the law" (p. 134) is such a transformation. The identity-theme is realized in terms of the domain of law and justice (wellknown to Schreber), and hence receives the form particular to Schreber's psychosis.

In our view, this is too vague to explain the particular form. The German system of law combined with the identity-theme does not suffice to explain the form of Schreber's delusional universe. We have shown (Vervaeck 1982) that such an explanation requires the study of the intricate relations between the social, the bodily and the cultural domains. That is, in order to understand Schreber's delusions, one must study them as articulations of the relations between these three domains, instead of seeing them as an articulation of one of them. For instance : it is insufficient to regard Schreber's world as a transformation of his (early) social relations (cf. Schatzman 1973), or of his bodiliness (cf. Schefer 1977) or of the culture and worldview he lived in (cf. Calasso 1976 ; Wilden 1977) - Schreber's world is a transformation of the relation between all these fields. a relation that is not to be captured fully in terms of "endangered autonomy". The transformation, in our view, must be located in the metaphorometonymical relations of double articulation between the fields. To explain transformations in terms of one field (viz., the legal field) is in itself insufficient ; Schreber's delusions cannot be understood unless they are studied from and within the above mentioned relations. 
One might reply that Chabot defends a similar relational standpoint : the identity-theme is relational, all phenomena are relations instead of entities. Chabot is also very anxious not to be considered a defender of "bourgeois individualism" (p. 78) : he wants to install a new approach that transcends the illusion of individuality. But he restricts the fundamental relation to one basic dyadic relation (with the mother) instead of seeing it as a multi-dimensional relation between social. cultural and bodily domains. More importantly, he never elaborates or defines his concept of autonomy. What then is the place of autonomy within the relations Chabot takes to be crucial? In other words: how can one define autonomy in relational terms and more specifically in terms of the dyadic relation with the mother which is precisely characterized by the lack of all sense of autonomy (cf. Anzieu's concept "le Moi-peau" : 1981:72) ? Autonomy should be defined in and through its relation with dependency, and there is no trace whatsoever of this in Chabot's book.

This is the reason why Chabot's interpretation is on the whole very unsatisfactory. One might argue that everyone fears to some extent that his autonomy will be endangered and that everyone suppresses aggression: why, then. is not everyone like Schreber? The concept of autonomy is so vague and general that it cannot be used to explain the uniqueness of Schreber's world. Certainly not when the concept is left undefined. This links up with the basic dualism : because Chabot refuses to use theoretical discourse in his interpretation. he insists that interpretation "use a variant of everyday speech" (p. 146). Bourdieu (1980b : 37ff. : 1982) has demonstrated that one cannot use the language of "le sens commun" without unknowingly reproducing the fundamental dualistic logic that structures this common sense. One of the fundamental dualisms in this logic of "la distinction" (Bourdieu 1979) is the one between theory and practice (id. : $81 \mathrm{ff}$.). This reveals the close relationship between Chabot's false dichotomy and his common sense interpretation. His rigid division implies his common sense interpretation which reproduces this division.

Chabot considers the Memoirs to be a sign of both art and madness (p. 1). This justifies an attempt to distill his view on literature and insanity starting from his interpretation of the Memoirs. It turns out that this view is an aftermath of the Romantic Weltanschauung. For instance: "The entire odyssey of Schreber's life (...) involves his futile struggle to undo a wounded sense of worth, to soothe an anguish at expectations left unfulfilled" (p. 143). Schreber's life and writings are seen as attempts to remedy a basic conflict that forms the onset to this life and these writings. All forms of creation are seen as springing from a conflict - a very Romantic view indeed. As we have explained above. Chabot regards life (and interpretation) as a process of unification effected via associative chains and on the 
basis of one fundamental conflict $\left({ }^{8}\right)$. From this vantage point, life. art. and madness are not really distinct : they are all attempts to remedy a conflict.

Chabot does not explicitate the differences between these various processes of unification that articulate a basic conflict into a synthesis via the associative chains. This makes his contribution to the theory and practice of the psychoanalytic interpretation (of madness and art) very doubtful. Schreber's Memoirs provide an excellent starting-point to elucidate the differences and correspondences between insanity and art. But Chabot has missed the chance. As long as the autonomy and dependency of the psychoanalytic and literary domains are not clarified, there can be no satisfying psycho-analytic interpretation of literature.

\section{References}

Anzieu. Didier (1981), Le corps de l'euvre : Essais psychanalytiques sur le travail créateur. Gallimard.

AUI.AGNIER, Piera Castoriadis (1975), La violence de l'interprétation : Du pictogramme à l'énoncé. Paris. P.U.F., (2nd edition 1981).

Bourdieu, Pierre (1979), La distinction : critique sociale du jugement. Paris, Minuit. (1980a), Le sens pratique. Paris, Minuit. - (1980b), Questions de sociologie. Paris. Minuit. - (1982). Ce que parler veut dire : l'économie des échanges linguistiques. Paris, Fayard.

CAL.Asso, Roberto (1976), Le fou impur. Paris. P.U.F., (traduit de l'italien : «Limpuro folle», Milan, 1974).

Снавот, C. Barry (1982), Freud on Schreber : Psychoanalytic Theory and the Critical Act. Amherst. Univ. of Massachusetts Press.

Felman. Shoshana (1977), To Open the Question. Yale French Studies 55/56 ('Literature and Psychoanalysis. The Question of Reading : Otherwise') : 5-10.

Foucaul.t, Michel (1969), L'archéologie du savoir. Gallimard.

Freud. Sigmund (1958), Psycho-analytic notes on an autobiographical account of a case of paranoia (dementia paranoides). In: J. Strachey (ed.). The Standurd Edition of the Complete Psychological Works of Sigmund Freud: vol. XII. London. Hogarth Press : 1-82. (First edition of Freud's essay : 1911).

Green. André (1977). Transcription dorigine inconnue. L'écriture du psychanalyste : critique du témoignage. Nouvelle Revue de Psychanalyse $16: 27-63$.

IsRafis. Han (1980), Schreber : Vader en Zoon. Academisch proefschrift. Amsterdam.

(8) Cf. R. B. White's study (1961) of the basic role played by the motherconflict in Schreber's psychosis. This neatly links up (be it from a more traditional viewpoint) with Chabot's theory of the fundamental relation and conflict as being generated by the relation with the mother. 
JeDdi, Essedik (ed.) (1982), Le corps en psychiatrie. Paris, Masson.

Junt. Peter (1980), Interpretation : An Essay in the Philosophy of Literary Criticism. Princeton. Princeton Univ. Press.

Kuiper, P.C. (1976), De mens en zijn verhaal. Amsterdam, Athenaeum - Polak \& Van Gennep.

Manonivi, Octave (1969), Schreber als Schreiber. In : O. Manonni, Clefs pour l'imaginaire ou l'autre scène. Paris. Seuil : 75-99.

Meissner, W. W. (S. J.) (1978), The Paranoid Process. New York/London, Jason Aronson.

Niedert.ANd, William G. (1974). The Schreber Case : Psychoanalytic Profile of a Paranoid Personality. New York, Quadrangle.

Pankow, Gisela (1969), L homme et sa psychose. Paris, Aubier, (2nd edition 1973).

Rabain. J.-F. (1980), Lectures du "cas Schreber". Revue francaise de Psychanalyse 2 : 329 347.

Racamier. P.-C. \& J. Chasseguet-Smirgel. (1966), La révision du cas Schreber : revue. Revue française de Psychanalyse $1: 3-61$.

Rosol.Ato, Guy (1978), La relation d'inconnu. Gallimard.

SAmI-At.ı (1977), Corps réel, corps imaginaire : pour une épistémologie psychanalytique. Paris, Dunod.

Schatzman, Morton (1973). Soul Murder : Persecution in the Family. London, Allen Lane.

SCHEFER. Jean-Louis (1977), Schreber : le symptôme et la paranoïa. In : A. Verdiglione (ed.), La Folie I : Actes du colloque de Milan 1976. Collection 10/18 : 345-355.

SChreber. Daniel Paul (1955), Memoirs of my nervous illness. London. WM Dawson, (Translated, Edited, with Introduction, Notes and Discussion by Ida Macalpine \& Richard A. Hunter). - (1973), Denkwürdigkeiten eines Nervenkranken. Frankfurt/ M. Ullstein Buch, (herausgegeben und eingeleitet von Samuel M. Weber). (First edition : 1903).

Sibony, Daniel (1974), Le nom et le corps. Paris, Seuil.

Skura. Meredith Anne (1981), The Literary Use of the Psychoanalytic Process. New Haven/London, Yale Univ. Press.

Vervaeck, Bart (1982), Autonomie en afhankelijkheid van de kunst : Een semantischpraksiologische benadering van het literair-kreatieve proces. Restant X, $3: 299$ 335.

Walters, Orville S. (1955). A methodological critique of Freuds Schreber analysis. The Psychoanalytic Review 4 : 321-342.

WhItE, Robert B. (1961), The mother-conflict in Schreber's psychosis. The International Journal of Psycho-A nalysis 42 : 55-73.

WII.DEN, Anthony (1977), System and Structure: Essays in Communication and Exchange. London. Tavistock, (esp. pp. 278-301).

Zenoni. Alfredo (1976), Métaphore et métonymie dans la théorie de Lacan. Cahiers internationaux de symbolisme 31-32: 187-198. 